\title{
Effects of Dangkwisoo-san, a traditional herbal medicine for treating pain and blood stagnation, on the pacemaker activities of cultured interstitial cells of Cajal
}

\author{
SOON-KI SUNG ${ }^{1}$, SUNG JIN KIM ${ }^{1}$, TAE SEOK AHN ${ }^{2}$, NOO RI HONG ${ }^{2}$, \\ HYUN SOO PARK ${ }^{2}$, YOUNG KYU KWON ${ }^{2}$ and BYUNG JOO KIM ${ }^{2}$ \\ ${ }^{1}$ Department of Neurosurgery, Pusan National University, Yangsan Hospital; \\ ${ }^{2}$ Division of Longevity and Biofunctional Medicine, School of Korean Medicine, Pusan National University, \\ Yangsan, Gyeongsangnam-do 626-870, Republic of Korea
}

Received October 2, 2014; Accepted July 17, 2015

DOI: $10.3892 / \mathrm{mmr} .2015 .4203$

\begin{abstract}
The interstitial cells of Cajal (ICCs) are the pacemaker cells in the gastrointestinal (GI) tract. In the present study, the effects of Dangkwisoo-san (DS) on pacemaker potentials in cultured ICCs from the small intestine of the mouse were investigated. The whole-cell patch-clamp configuration was used to record pacemaker potentials from cultured ICCs and the increase in intracellular $\mathrm{Ca}^{2+}$ concentration $\left(\left[\mathrm{Ca}^{2+}{ }_{\mathrm{i}}\right)\right.$ was analyzed in cultured ICCs using fura-2-acetoxymethyl ester. The generation of pacemaker potentials in the ICCs was observed. DS produced pacemaker depolarizations in a concentration dependent manner in current clamp mode. The 4-diphenylacetoxy-N-methyl-piperidine methiodide muscarinic $\mathrm{M}_{3}$ receptor antagonist inhibited DS-induced pacemaker depolarizations, whereas methoctramine, a muscarinic $\mathrm{M}_{2}$ receptor antagonist, did not. When guanosine 5'-[ $\beta$-thio] diphosphate (GDP- $\beta$-S; $1 \mathrm{mM}$ ) was in the pipette solution, DS marginally induced pacemaker depolarizations, whereas low $\mathrm{Na}^{+}$solution externally eliminated the generation of pacemaker potentials and inhibited the DS-induced pacemaker depolarizations. Additionally, the nonselective cation channel blocker, flufenamic acid, inhibited the DS-induced pacemaker depolarizations. Pretreatment with $\mathrm{Ca}^{2+}$-free solution and thapsigargin, a $\mathrm{Ca}^{2+}$-ATPase inhibitor in the endoplasmic reticulum, also eliminated the generation of pacemaker currents and suppressed the DS-induced pacemaker depolarizations. In addition, $\left[\mathrm{Ca}^{2+}\right]_{\mathrm{i}}$ analysis revealed that DS increased $\left[\mathrm{Ca}^{2+}\right]_{\mathrm{i}}$. These results suggested that DS modulates
\end{abstract}

Correspondence to: Professor Byung Joo Kim, Division of Longevity and Biofunctional Medicine, School of Korean Medicine, Pusan National University, Beomeori, Mulgeum-eup, Yangsan, Gyeongsangnam-do 626-870, Republic of Korea

E-mail: vision@pusan.ac.kr

Key words: interstitial cells of Cajal, pacemaker potentials, Dangkwisoo-san, gastrointestinal tract pacemaker potentials through muscarinic $\mathrm{M}_{3}$ receptor activation in ICCs by $\mathrm{G}$ protein-dependent external and internal $\mathrm{Ca}^{2+}$ regulation and external $\mathrm{Na}^{+}$. Therefore, DS were observed to affect intestinal motility through ICCs.

\section{Introduction}

Traditional herbal medicine is considered to be one of the most important complementary or alternative medicines in the majority of countries, and has been increasingly accepted worldwide. Despite substantial advances in modern scientific medicine, traditional medicine remains the primary form of treatment, which is readily available to the majority of individuals in several countries (1). Traditional herbal medicines usually contain a number of compounds, which affect multiple targets $(2,3)$. The combination of multiple drugs is considered to maximize therapeutic efficacy by facilitating synergistic actions and preventing potential adverse effects (2). Dangkwisoo-san (DS) is a herbal formula, which has been traditionally used for the treatment of pain and blood stagnation caused by physical trauma in Korea (4). DS contains constituents of nine species of herbal plants, including Angelicae gigantis Radix, Paeoniae Radix, Linderae Radix, Sappan Lignum, Cyperi Rhizoma, Carthami Flos, Persicae Semen, Cinnamomi Cortex and Glycyrrhizae Radix et Rhizoma, which have various pharmacological effects on the body $(5,6)$. However, no investigations regarding the effects of DS on gastrointestinal (GI) motility have been previously performed, to the best of our knowledge.

The interstitial cells of Cajal (ICCs) are the pacemaker cells of the GI system and have multifunctional roles. ICCs generate rhythmic oscillations in membrane potential, termed slow waves (7-9). The loss of ICCs is implicated in various motility disorders, which indicates that ICCs are important in the regulation of GI motility (10). In addition, endogenous agents, including neurotransmitters, hormones and paracrine substances, modulate GI tract motility by affecting ICCs. Thus, in investigating GI motility, ICCs are the major area of interest and, at present, several novel drugs are being developed in the area of GI motility utilizing ICCs. Therefore, the present study 
investigated whether DS affects the pacemaker potentials of cultured ICCs and characterized the CCK receptor subtypes involved.

\section{Materials and methods}

Ethics. Animal care and experiments were conducted in accordance with the guidelines issued by the ethics committee of Pusan National University (Busan, Republic of Korea; Approval no. PNU-2014-0725) and the National Institutes of Health Guide for the Care and Use of Laboratory Animals.

Preparation of cells and cell cultures. Male and female BALB/c mice [age, 3-7 days; $n=75$ (male: 56\%; female: $44 \%$ ) obtained from Samtako Bio Korea Inc. (Osan, Korea)] were anesthetized with $99 \%$ ether (Sigma-Aldrich, St. Louis, MO, USA) and sacrificed by cervical dislocation. The small intestines in the region between $1 \mathrm{~cm}$ below the pyloric ring and the cecum were removed and opened along the mesenteric border. The luminal contents were removed by washing with Krebs-Ringer bicarbonate solution (Sigma-Aldrich). The tissues were pinned to the base of a Sylgard dish and the was mucosa removed by sharp dissection. Small tissue strips $(0.2 \times 0.2$ inches) of the intestinal muscle, consisting of circular and longitudinal muscle, were equilibrated in $\mathrm{Ca}^{2+}$-free Hanks' solution (containing $5.36 \mathrm{mmol} / 1 \mathrm{KCL}$, $125 \mathrm{mmol} / 1 \mathrm{NaCl}, 0.34 \mathrm{mmol} / \mathrm{l} \mathrm{NaOH}, 0.44 \mathrm{mmol} / 1 \mathrm{Na}_{2} \mathrm{HCO}_{3}$, $10 \mathrm{mmol} / 1$ glucose, $2.9 \mathrm{mmol} / 1$ sucrose and $11 \mathrm{mmol} / 1 \mathrm{HEPES}$; Sigma-Aldrich) for $30 \mathrm{~min}$. Subsequently, the cells (density, $85 \%$ ) were dispersed using an enzyme solution containing $1.3 \mathrm{mg} / \mathrm{ml}$ collagenase (Worthington Biochemical Co., Lakewood, NJ, USA), $2 \mathrm{mg} / \mathrm{ml}$ bovine serum albumin (Sigma-Aldrich), $2 \mathrm{mg} / \mathrm{ml}$ trypsin inhibitor (Sigma-Aldrich) and $0.27 \mathrm{mg} / \mathrm{ml}$ ATP (Sigma-Aldrich). The cells were plated onto sterile glass coverslips coated with murine collagen $(2.5 \mu \mathrm{g} / \mathrm{ml}$, BD Biosciences, Franklin Lakes, NJ, USA) in a $35-\mathrm{mm}$ culture dish and then cultured at $37^{\circ} \mathrm{C}$ in a $95 \% \mathrm{O}_{2}$, $50 \mathrm{ml} / 1 \mathrm{CO}_{2}$ incubator in a smooth muscle growth medium (Clonetics Corp., San Diego, CA, USA) supplemented with 2\% antibiotics/antimycotics (Gibco Life Technologies, Grand Island, NY, USA) and murine stem cell factor (SCF; $5 \mathrm{ng} / \mathrm{ml}$; Sigma-Aldrich). The ICCs were identified immunologically by incubation with an anti-c-kit antibody (cat. no. 12-1172; phycoerythrin-conjugated rat anti-mouse c-kit monoclonal antibody; eBioscience, San Diego, CA, USA) at a dilution of 1:50 for $20 \mathrm{~min}$ (11). The ICCs were morphologically distinct from other cell types in the culture, enabling the identification of the cells using phase contrast microscopy (IX-71; Olympus Corporation, Tokyo, Japan) once they had been verified with the anti c-kit antibody.

Patch-clamp experiments. The whole-cell patch-clamp configuration was used to record membrane potentials (current clamp) from the cultured ICCs. An axopatch ID (Axon Instruments, Inc., Foster City, CA, USA) was used to amplify membrane currents and potentials. The command pulse was applied using an IBM-compatible personal computer and pClamp software (version 6.1; Axon Instruments, Inc.). The data obtained were filtered at $5 \mathrm{kHz}$ and viewed on an
HM507 oscilloscope (Hameg Instruments GmbH, Melrose, MA, USA), a computer monitor and using a pen recorder (Gould 2200; Gould, Valley View, OH, USA). The results were analyzed using pClamp and Origin (version 6.0) software (MicroCal, Northampton, MA, USA). All experiments were performed at $30-32^{\circ} \mathrm{C}$.

Fura-2-acetoxymethyl ester (Fura-2-AM) loading and measurement of intracellular free calcium ion concentration $\left[\mathrm{Ca}^{2+}\right]_{i}$. The cultured ICC clusters were loaded with $5 \mu \mathrm{mol} / 1$ of the acetoxymethyl ester form of fura-2 (Molecular ProbesLife Technologies, Carlsbad, CA, USA), diluted from a $1 \mathrm{mmol} / 1$ stock in dimethyl sulfoxide (DMSO; Sigma-Aldrich), in normal medium for $20 \mathrm{~min}$ at $37^{\circ} \mathrm{C}$. The recording of $\left[\mathrm{Ca}^{2+}\right]$ i was performed using a microfluorometric system consisting of an inverted fluorescence microscope (Diaphot 300; Nikon Corporation, Tokyo, Japan) with a dry-type fluorescence objective lens (40X; numerical aperture 0.85), a photomultiplier tube (type R 1527; Hamamatsu, Shizuoka, Japan), and a PTI-Deltascan illuminator (Photon Technology International, Inc., Edison, NJ, USA). The cells were superfused at a flow rate of $1.5 \mathrm{ml} / \mathrm{min}$. Light was provided by a $75-\mathrm{W}$ xenon lamp (UXL-75XE; Ushio, Japan). To control the excitation frequency, a chopper wheel was used to alternate the light path to monochromators (340 and $380 \mathrm{~nm}$ ) with a frequency of 5 or $10 \mathrm{~Hz}$. A short-pass dichroic mirror passed an emission light of $<570 \mathrm{~nm}$ onto the photomultiplier tube, and the intensity was measured at $510 \mathrm{~nm}$. A mechanical image mask was placed in the emission path to limit measurement to a single cell. Data acquisition and control of light application were performed using computer software (Felix version 1.1; Photon Technology International, Inc.). Due to uncertainties in calibrating the fura- 2 signals in intact cells, no calibration of $\left[\mathrm{Ca}^{2+}\right]_{\mathrm{i}}$ was performed; instead, all results are reported as changes in the $340 \mathrm{~nm} / 380 \mathrm{~nm}$ signal ratio.

Solutions and drugs. The physiological salt solution used to bathe cells ( $\mathrm{Na}^{+}$-Tyrode) contained $5 \mathrm{mmol} / \mathrm{l} \mathrm{KCl}$, $135 \mathrm{mmol} / 1 \mathrm{NaCl}, 2 \mathrm{mmol} / \mathrm{CaCl}_{2}, 10 \mathrm{mmol} / 1$ glucose, $1.2 \mathrm{mmol} / 1 \mathrm{MgCl}_{2}$ and $10 \mathrm{mmol} / \mathrm{l} \mathrm{HEPES}$, and was adjusted to $\mathrm{pH} 7.4$ with $\mathrm{NaOH}$. The pipette solution contained $140 \mathrm{mmol} / 1 \mathrm{KCl}, 5 \mathrm{mmol} / 1 \mathrm{MgCl}_{2}, 2.7 \mathrm{mmol} / 1 \mathrm{~K}_{2} \mathrm{ATP}$, $0.1 \mathrm{mmol} / 1 \mathrm{NaGTP}, 2.5 \mathrm{mmol} / \mathrm{l}$ creatine phosphate disodium, $5 \mathrm{mmol} / 1 \mathrm{HEPES}$ and $0.1 \mathrm{mmol} / 1 \mathrm{EGTA}$, adjusted to $\mathrm{pH} 7.2$ with $\mathrm{KOH}$. To evaluate the effect of guanosine 5 '-[ $\beta$-thio] diphosphate (GDP- $\beta-S$; Sigma-Aldrich) on ICCs, GDP- $\beta-S$ was included in the pipette solution. DS is composed of nine species of herbal plants, each of which were purchased from Kwangmyungdang Natural Pharmaceutical Co. (Ulsan, Korea). The constituents and formula of DS is described in Table I. A total of $60 \mathrm{~g}$ DS was boiled in 1 liter of distilled water in a Herb Extractor (DW-290; Daewoong Pharmaceutical Co., Ltd., Seoul, Korea) for 2 h, yielding a final $200 \mathrm{ml}$ volume containing the DS extract. The supernatant was harvested in sterile conditions by centrifugation $\left(110 \mathrm{x} \mathrm{g}\right.$ at $4^{\circ} \mathrm{C}$ for $\left.3 \mathrm{~min}\right)$ and lyophilized through evaporation at $-80^{\circ} \mathrm{C}$, yielding a final quantity of $4.6 \mathrm{~g}$. The lyophilized DS extract was dissolved in $500 \mu \mathrm{l}$ sterile phosphate-buffered saline prior to administration to the cells. The water extract of DS (voucher no. MH2014-0001) 
Table I. Composition of Dangkwisoo-san.

Scientific name

Herbal name

Quantity (g)

Angelica gigas Nakai

Angelicae gigantis Radix

5.625

Paeonia lactiflora Pall

Paeoniae Radix

3.750

Lindera strichnifolia Fern'andez-Villar

Linderae Radix

3.750

Caesalpinia sappan L.

Sappan Lignum

3.750

Cyperus rotundus L.

Cyperi Rhizoma

3.750

Carthamus tinctorious L.

Carthami Flos

3.000

Prunus persica Batsch

Persicae Semen

2.655

Cinnamomum cassia

Presl Cinnamomi Cortex

2.250

Glycyrrhiza uralensis Fisch

Glycyrrhizae Radix et Rhizoma

1.875

Total quantity: $30.405 \mathrm{~g}$.

A

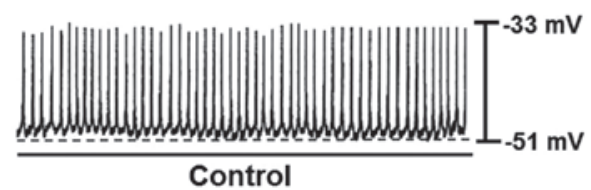

B

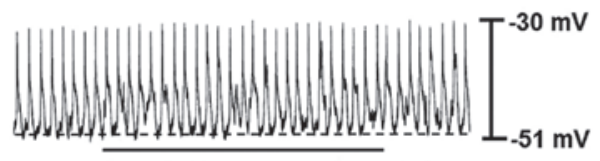

C

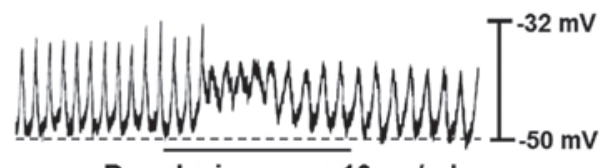

Dangkwisoo-san $10 \mu \mathrm{g} / \mathrm{ml}$

D

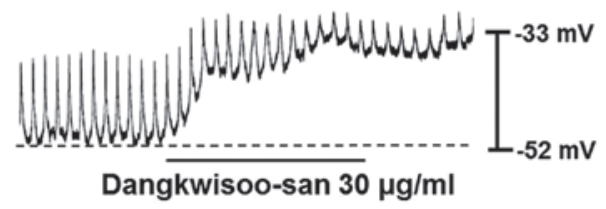

E

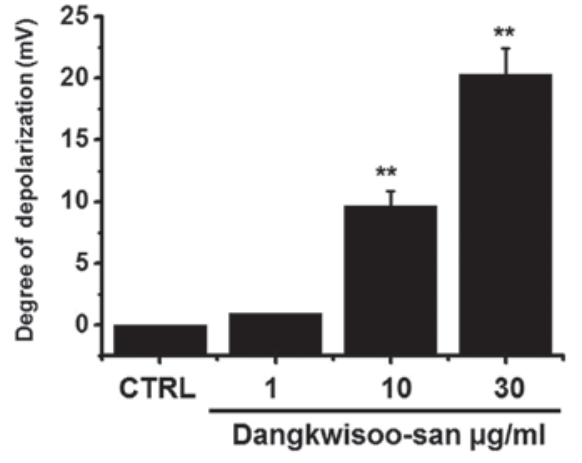

Figure 1. Effects of DS on pacemaker potentials in cultured ICCs from the murine small intestine. (A-D) Pacemaker potentials of ICCs exposed to DS $(0-30 \mu \mathrm{g} / \mathrm{ml})$ in current clamping mode $(\mathrm{I}=0)$. (E) Summary of responses to DS. Bars indicate the mean \pm standard error of the mean. ${ }^{* *} \mathrm{P}<0.01$, compared with untreated controls. CTRL, control; DS, Dangkwisoo-san; ICCs, interstitial cells of Cajal.

was deposited at the Division of Longevity and Biofunctional Medicine, School of Korean Medicine, Pusan National University (Pusan, Korea). All other drugs were obtained from Sigma-Aldrich. The drug treatments were dissolved in distilled water and added to bath solution to produce the desired concentrations, just prior to use. The addition of these chemicals to the bath solution did not alter the $\mathrm{pH}$ of the solution. 4-Diphenylacetoxy-N-methyl-piperidine methiodide [4-DAMP; $10 \mu \mathrm{M}$ (Sigma-Aldrich)] and $5 \mu \mathrm{M}$ thapsigargin (Sigma-Aldrich) were dissolved in DMSO for a $50 \mathrm{mmol} / 1$ stock solution and added to the bathing solution on the day of the experiment. The final concentration of DMSO in the bath solution remained $<0.1 \%$, and it was confirmed that this concentration of DMSO did not affect the results recorded. In addition, $25 \mu 1$ methoctramine (Sigma-Aldrich) was dissolved in distilled water for a $50 \mathrm{mmol} / 1$ stock solution and added to the bathing solution on the day of the experiment.
Statistical analysis. All data are expressed as the mean \pm standard error of the mean. Student's t-test for unpaired data was used to compare the control and experimental groups. Origin statistical software (version 6.0) was used to perform statistical analyses (MicroCal) and $\mathrm{P}<0.05$ was considered to indicate a statistically significant difference.

\section{Results}

Effect of DS on pacemaker potentials in cultured ICCs. Initially, the effects of DS on pacemaker potentials were examined. Recordings from cultured ICCs under current clamp mode $(\mathrm{I}=0)$ revealed spontaneous pacemaker potentials. The resting membrane potential was $-51.4 \pm 2.6 \mathrm{mV}$ and the amplitude was $20.2 \pm 2.3 \mathrm{mV}$. In the presence of DS $(1-30 \mu \mathrm{g} / \mathrm{ml})$, the membrane potentials were depolarized to $1.0 \pm 0.1 \mathrm{mV}$ at $1 \mu \mathrm{g} / \mathrm{ml}, 9.7 \pm 1.3 \mathrm{mV}$ at $10 \mu \mathrm{g} / \mathrm{ml}$ and $20.5 \pm 2.2 \mathrm{mV}$ at $30 \mu \mathrm{g} / \mathrm{ml}$ 
A

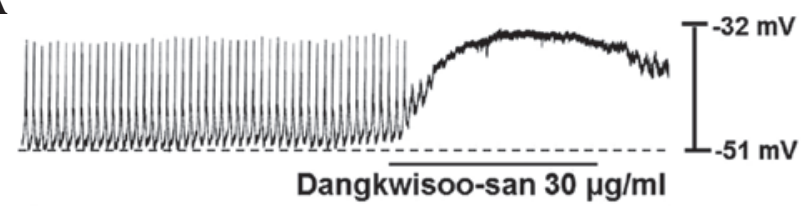

Methoctramine $10 \mu \mathrm{M}$

B

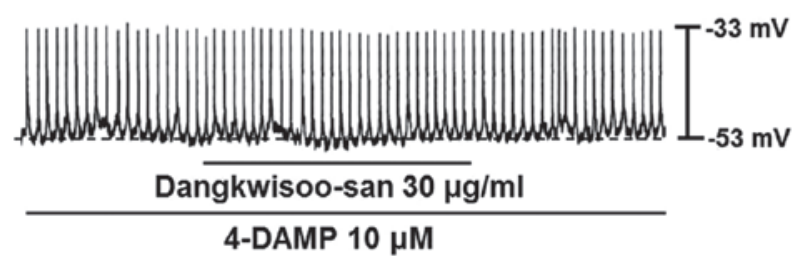

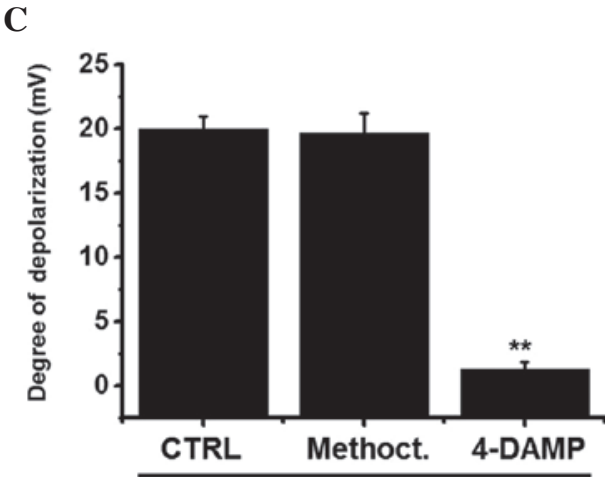

Dangkwisoo-san $30 \mu \mathrm{g} / \mathrm{ml}$

Figure 2. Effects of muscarinic receptor subtype antagonists on DS-induced pacemaker potential depolarizations in cultured ICCs. (A) Pacemaker potentials of ICCs exposed to DS $(30 \mu \mathrm{g} / \mathrm{ml})$ in the presence of methoctramine muscarinic $\mathrm{M}_{2}$ receptor antagonist $(10 \mu \mathrm{M})$. Pacemaker potentials were depolarized. (B) Pacemaker potentials of ICCs exposed to DS in the presence of 4-DAMP muscarinic $\mathrm{M}_{3}$ receptor antagonist (10 $\left.\mu \mathrm{M}\right)$. Pacemaker potentials were not altered. (C) Responses to DS in the presence of different receptor antagonists. Error bars indicate the mean \pm standard error of the mean. ${ }^{* *} \mathrm{P}<0.01$, compared with untreated controls. CTRL, control; Methoct, methoctramine; DS, Dangkwisoo-san; ICCs, interstitial cells of Cajal; 4-DAMP, 4-diphenylacetoxy-N-methyl-piperidine methiodide.

A

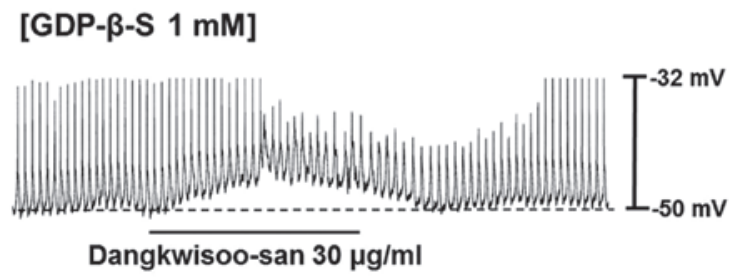

B

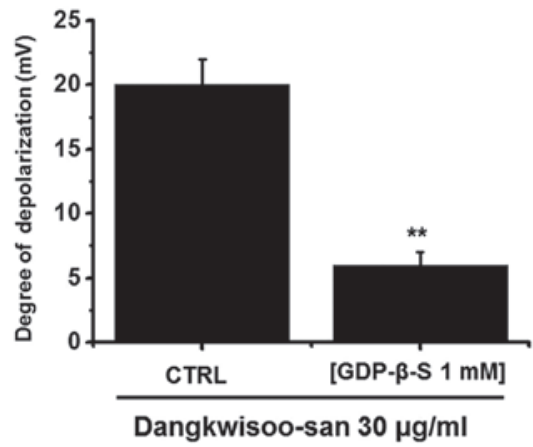

Figure 3. Effects of GDP- $\beta$-S in the pipette on DS-induced pacemaker potential depolarizations in cultured ICCs of the murine small intestine. (A) Pacemaker potentials of ICCs exposed to DS $(30 \mu \mathrm{g} / \mathrm{ml})$ in the presence of GDP- $\beta-\mathrm{S}(1 \mathrm{mM})$ in the pipette. Under these conditions, DS (30 $\mu \mathrm{g} / \mathrm{ml})$ marginally induced pacemaker potential depolarizations. (B) Responses to DS in the presence of GDP- $\beta-S$ in the pipette. Bars indicate the mean \pm standard error of the mean. ${ }^{* *} \mathrm{P}<0.01$, compared with untreated controls. CTRL, control; DS, Dangkwisoo-san; ICCs, interstitial cells of Cajal; GDP- $\beta$-S, guanosine 5'-[ $\beta$-thio] diphosphate.

(Fig. 1A-D). The summarized values and bar graph of the DS effects on pacemaker potentials are shown in Fig. $1 \mathrm{E}(\mathrm{n}=6)$. These results suggested that DS had a pacemaker depolarization effect on the ICCs.

Identification of DS receptor subtypes in cultured ICCs. To investigate the association between DS and its receptors, muscarinic receptors were investigated as they are known to mediate the membrane depolarization and excitatory junction potential in the GI tract $(12,13)$. In the GI tract, isolated ICCs express the $M_{2}$ and $M_{3}$ subtypes of the muscarinic receptors (14). To identify the muscarinic receptor subtypes involved in the effects of DS, the ICCs were pretreated with muscarinic receptor antagonists and then treated with DS. Methoctramine, a muscarinic $\mathrm{M}_{2}$ receptor antagonist, and 4-DAMP, a muscarinic $M_{3}$ receptor antagonist, were used for pretreatment at a concentration of $10 \mu \mathrm{M}$ for $5 \mathrm{~min}$ and DS was added. Treatment with methoctramine or 4-DAMP had no effect on pacemaker potentials. Pretreatment with methoctramine did not inhibit the effect of DS (Fig. 2A), and the membrane depolarization produced in the presence of methoctramine by
DS was $19.6 \pm 2.1 \mathrm{mV}(\mathrm{n}=5)$. However, following pre-treatment with 4-DAMP, membrane depolarization by DS was found to be inhibited (Fig. 2B), and the membrane depolarization produced in the presence of 4-DAMP by DS was $1.3 \pm 0.5 \mathrm{mV}$ (n=6; Fig. 2C). These results suggested that DS had an effect on the ICCs through the $\mathrm{M}_{3}$ receptor.

Involvement of $G$ proteins in DS-induced depolarizations of pacemaker potentials in cultured ICCs. The effects of GDP- $\beta$-S, a non-hydrolysable guanosine 5'-diphosphate analogue, which permanently inactivates G-protein binding proteins $(15,16)$ were examined to determine whether G-proteins are involved in the effects of DS on cultured ICCs. DS $(30 \mu \mathrm{g} / \mathrm{ml})$ induced membrane depolarizations in ICCs (Fig. 1). However, when GDP- $\beta-S(1 \mathrm{mM})$ was in the pipette solution, DS $(30 \mu \mathrm{g} / \mathrm{ml})$ induced the membrane depolarizations only marginally (Fig. 3A). The membrane depolarizations induced by DS were significantly affected by the presence of GDP- $\beta-S(1 \mathrm{mM})$ in the pipette solution $(\mathrm{n}=5$; Fig. $3 \mathrm{~B})$. These results suggested that $\mathrm{G}$-proteins are involved in the DS-induced pacemaker depolarizations in ICCs. 
A

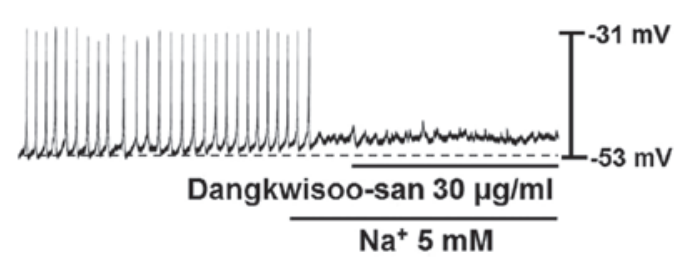

B

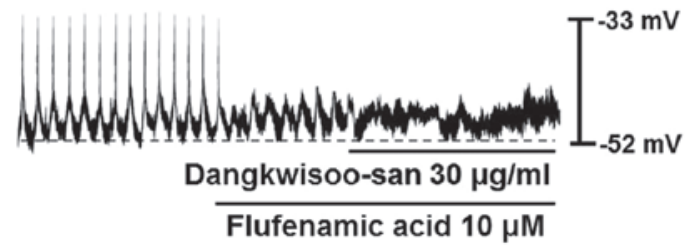

C

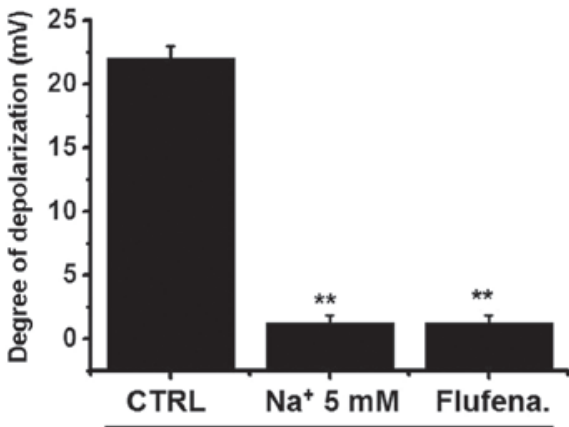

Dangkwisoo-san $30 \mu \mathrm{g} / \mathrm{ml}$

Figure 4. Effects of external low $\mathrm{Na}^{+}$solution or flufenamic acid, a nonselective cation channel blocker, on DS-induced pacemaker potential depolarizations in cultured ICCs of the murine small intestine. (A) External low $\mathrm{Na}^{+}$solution eliminated the generation of pacemaker potentials. Under these conditions, DS did not depolarize pacemaker potentials. (B) Flufenamic acid $(10 \mu \mathrm{M})$ eliminated the generation of pacemaker potentials. In these conditions, flufenamic acid inhibited the DS-induced pacemaker potential depolarizations. (C) Responses to DS in the external low $\mathrm{Na}^{+}$solution and in the presence of flufenamic acid Bars indicate the mean \pm standard error of the mean. ${ }^{* *} \mathrm{P}<0.01$, compared with untreated controls. CTRL, control; DS, Dangkwisoo-san; ICCs, interstitial cells of Cajal.

A

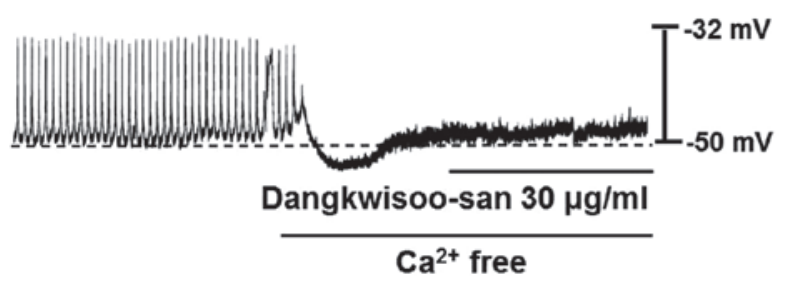

B

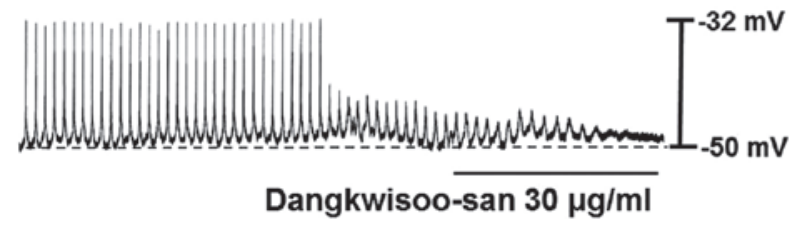

Thapsigargin $5 \mu \mathrm{M}$
C

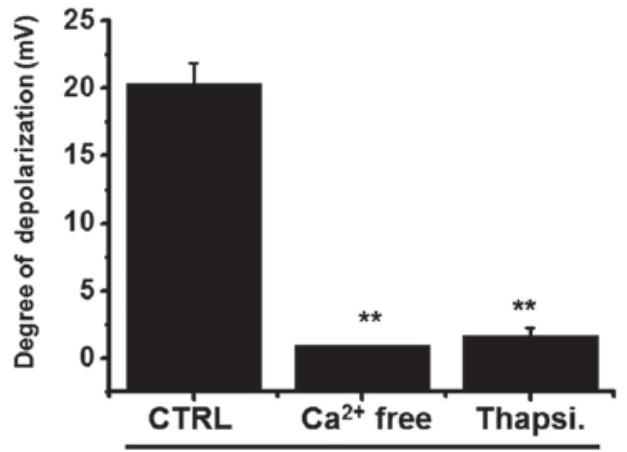

Dangkwisoo-san $30 \mu \mathrm{g} / \mathrm{ml}$

Figure 5. Effects of an external $\mathrm{Ca}^{2+}$-free solution and of thapsigargin (a $\mathrm{Ca}^{2+}$-ATPase inhibitor in endoplasmic reticulum) on DS-induced pacemaker potential depolarizations in cultured ICCs. (A) External $\mathrm{Ca}^{2+}$-free solution eliminated the generation of pacemaker potentials and inhibited the DS-induced pacemaker potential depolarizations. (B) Thapsigargin $(5 \mu \mathrm{M})$ eliminated pacemaker potential depolarizations and inhibited DS-induced pacemaker potential depolarizations. (C) Responses to DS in external $\mathrm{Ca}^{2+}$-free solution and in the presence of thapsigargin. Bars indicate the mean \pm standard error of the mean. ** $\mathrm{P}<0.01$, compared with untreated controls. CTRL, control; DS, Dangkwisoo-san; ICCs, interstitial cells of Cajal.
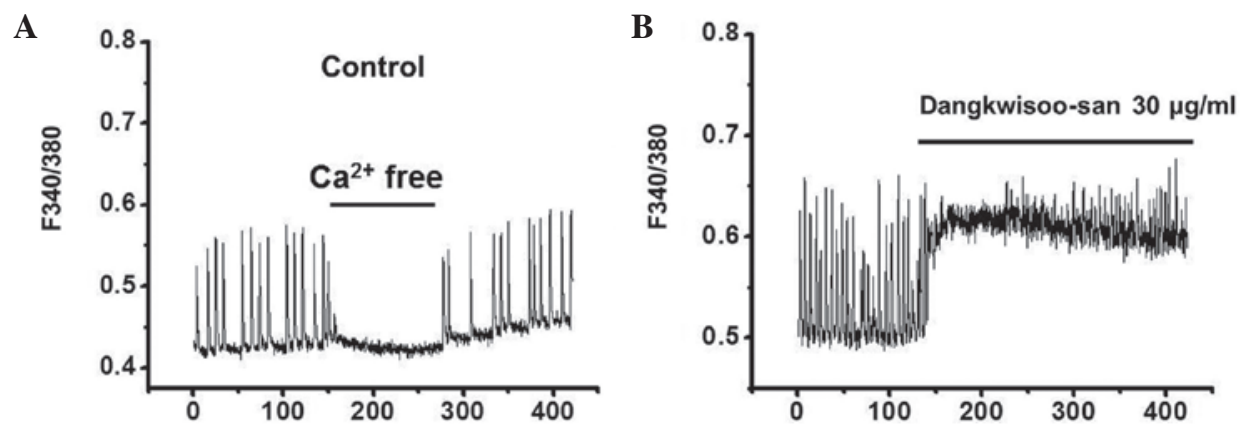

Figure 6. Responses of intracellular $\mathrm{Ca}^{2+}$ to DS in cultured ICCs. Increase in $\left[\mathrm{Ca}^{2+}\right]_{\mathrm{i}}$ was plotted against DS concentrations. (A) In normal conditions, $\left[\mathrm{Ca}^{2+}\right]_{i}$ oscillations were induced. (B) DS $(30 \mu \mathrm{g} / \mathrm{ml})$ caused a sustained increase in $\left[\mathrm{Ca}^{2+}\right]_{\mathrm{i}}$. DS, Dangkwisoo-san.

Effects of low external $\mathrm{Na}^{+}$concentration or nonselective cation channel blocker on DS-induced depolarizations in pacemaker potentials in cultured ICCs. To determine the characteristics of the pacemaker depolarizations induced by DS, a low external $\mathrm{Na}^{+}$concentration solution and a nonselective cation channel blocker were assessed. External $\mathrm{Na}^{+}$was substituted for by the 
same concentrations of $N$-methyl-D-glucamine. In the presence of an external $\mathrm{Na}^{+} 5 \mathrm{mM}$ solution, pacemaker potentials were eradicated. Under these conditions, DS $(30 \mu \mathrm{g} / \mathrm{ml})$ did not induce pacemaker depolarizations (Fig. 4A). In the external $\mathrm{Na}^{+} 5 \mathrm{mM}$ solution, the pacemaker depolarizations produced by $\mathrm{DS}$ were $1.4 \pm 0.4 \mathrm{mV}$, which was significantly different, compared with the normal control solution (n=6; Fig. 4). In the presence of flufenamic acid $(10 \mu \mathrm{M})$, a nonselective cation channel blocker, the pacemaker potentials were eradicated. Additionally, in these conditions, DS did not induce pacemaker depolarizations (Fig. 4B). Following pretreatment with flufenamic acid, the pacemaker depolarizations produced by DS were $1.3 \pm 0.6 \mathrm{mV}$, which was significantly different, compared with the normal control solution ( $n=5$; Fig. 4C). These results suggested that external $\mathrm{Na}^{+}$and nonselective cation channels are involved in DS-induced depolarizations in pacemaker potentials in cultured ICCs.

Effects of external $\mathrm{Ca}^{2+}$-free solution and $\mathrm{Ca}^{2+}$-ATPase inhibitors of endoplasmic reticulum on DS-induced depolarizations on pacemaker potentials in cultured ICCs. To investigate the role of external $\mathrm{Ca}^{2+}$ or internal $\mathrm{Ca}^{2+}$, DS was applied under external $\mathrm{Ca}^{2+}$-free conditions and in the presence of thapsigargin, a $\mathrm{Ca}^{2+}$-ATPase inhibitor of endoplasmic reticulum. In external $\mathrm{Ca}^{2+}$-free solution, pacemaker potentials were completely eradicated. In this condition, DS had no effect on pacemaker potentials (Fig. 5A). These effects were significantly different, compared with those of DS in the normal $\mathrm{Ca}^{2+}$ solution ( $n=6$; Fig. 5). In addition, pretreatment with thapsigargin $(5 \mu \mathrm{M})$ suppressed the pacemaker potentials and, in this condition, DS had no effect on pacemaker potentials (Fig. 5B). In the presence of thapsigargin, the effects were significantly different, compared with DS in the absence of thapsigargin ( $n=6$; Fig. 5C). These results suggested that external $\mathrm{Ca}^{2+}$ or internal $\mathrm{Ca}^{2+}$ regulations are important in modulating pacemaker potentials in cultured ICCs.

Response of $\left[\mathrm{Ca}^{2+}\right]_{i}$ to $\mathrm{DS}$. To investigate the effects of DS on $\left[\mathrm{Ca}^{2+}\right]_{\mathrm{i}}$ oscillations, spontaneous $\left[\mathrm{Ca}^{2+}\right]_{\mathrm{i}}$ oscillations were measured in ICCs clusters. This was due to the fact that $\left[\mathrm{Ca}^{2+}\right]_{\mathrm{i}}$ oscillations in ICCs are primarily responsible for GI pacemaker activity (17). Spontaneous $\left[\mathrm{Ca}^{2+}\right]_{\mathrm{i}}$ oscillations were observed in ICC clusters treated with $5 \mu \mathrm{M}$ fura-2-AM Fig. 6 shows the changes in the $340 \mathrm{~nm} / 380 \mathrm{~nm}$ signal ratio. In normal conditions, spontaneous $\left[\mathrm{Ca}^{2+}\right]_{\mathrm{i}}$ oscillations were induced (Fig. 6A). In the presence of DS $(30 \mu \mathrm{g} / \mathrm{ml})$, the $\left[\mathrm{Ca}^{2+}\right]$ ${ }_{i}$ in ICCs was increased (Fig. 6B). These results suggested that DS increased the $\left[\mathrm{Ca}^{2+}\right]_{\mathrm{i}}$ in ICCs.

\section{Discussion}

In the present study, ICCs were used to investigate the association between DS and GI motility. DS has not been previously used to treat GI motility diseases, and this is the first study, to the best of our knowledge, regarding the potential effects of DS on ICCs. Due to the central role of ICCs in GI motility, loss of these cells is detrimental in disorders, including inflammatory bowel disease, chronic idiopathic intestinal pseudo-obstruction, intestinal obstruction with hypertrophy, achalasia, Hirschsprung disease, juvenile pyloric stenosis, juvenile intestinal obstruction and anorectal malformation (10). Therefore, investigation into the biology of ICCs provides novel opportunities to develop drugs with the ability to regulate GI motility.

Acetylcholine depolarizes the membrane potential of slow waves and leads to contraction of gastrointestinal smooth muscle (18). Therefore, muscarinic receptors are important in the regulation of GI motility. Muscarinic receptors are composed of five subtypes, $\mathbf{M}_{1}-\mathbf{M}_{5}$. However, GI smooth muscles express the $\mathrm{M}_{2}$ and $\mathrm{M}_{3}$ subtypes of the muscarinic receptors. $M_{2}$ receptors are more widely distributed than $M_{3}$ receptors, in the ratio of $80 \% \mathrm{M}_{2}$ to $20 \% \mathrm{M}_{3}$ (19). In molecular studies, mRNA of $\mathrm{M}_{2}$ and $\mathrm{M}_{3}$ receptors were detected using reverse-transcription polymerase chain reaction from isolated ICCs (14). In the present study, 4-DAMP, a muscarinic $\mathrm{M}_{3}$ receptor antagonist, inhibited DS-induced pacemaker depolarizations, whereas methoctramine, a muscarinic $\mathrm{M}_{2}$ receptor antagonist, did not. Thus, it appears that DS modulated pacemaker potentials through muscarinic $\mathrm{M}_{3}$ receptor-mediated pathways in the ICCs of the mouse small intestine (Fig. 2).

Generally, DS has been traditionally used in Korea for the treatment of pain and blood stagnation caused by physical trauma (4). In the present study, however, it was found that DS modulated GI motility using ICCs. DS produced pacemaker depolarizations in current clamp mode (Fig. 1). 4-DAMP, a muscarinic $M_{3}$ receptor antagonist, inhibited DS-induced pacemaker depolarizations, whereas methoctramine, a muscarinic $M_{2}$ receptor antagonist, did not (Fig. 2). When GDP- $\beta$-S $(1 \mathrm{mM})$ was included in the pipette solution, DS induced pacemaker depolarizations marginally (Fig. 3). Low $\mathrm{Na}^{+}$solution externally inhibited the DS-induced pacemaker depolarizations. Additionally, the nonselective cation channel blocker, flufenamic acid, inhibited the DS-induced pacemaker depolarizations (Fig. 4). Pretreatment with $\mathrm{Ca}^{2+}$-free solution and thapsigargin, a $\mathrm{Ca}^{2+}$-ATPase inhibitor in the endoplasmic reticulum, suppressed the DS-induced pacemaker depolarizations (Fig. 5). In addition, $\left[\mathrm{Ca}^{2+}\right]_{\mathrm{i}}$ analysis revealed that DS increased $\left[\mathrm{Ca}^{2+}\right]_{\mathrm{i}}$ (Fig. 6). These results suggested that DS may affect GI motility via the modulation of pacemaker potentials through muscarinic $\mathrm{M}_{3}$ receptor activation by a $\mathrm{G}$ protein-dependent external and internal $\mathrm{Ca}^{2+}$ regulation and external $\mathrm{Na}^{+}$in ICCs.

In conclusion, the present data suggested that DS may have an ability to modulate the pacemaker potentials in ICCs. In future investigations, the active compounds within DS and their mechanism of action require detailed investigation.

\section{Acknowledgements}

This study was supported by a National Research Foundation of Korea Grant funded by the Korean government (grant no. 2014R1A5A2009936).

\section{References}

1. Jiang M, Yang J, Zhang C, Liu B, Chan K, Cao H and Lu A: Clinical studies with traditional Chinese medicine in the past decade and future research and development. Planta Med 76: 2048-2064, 2010.

2. Qiu J: 'Back to the future' for Chinese herbal medicines. Nat Rev Drug Discov 6: 506-507, 2007. 
3. Wang L, Zhou GB, Liu P, Song JH, Liang Y, Yan XJ, Xu F, Wang BS, Mao JH, Shen ZX, et al: Dissection ofmechanisms of Chinese medicinal formula Realgar-Indigo naturalis as an effective treatment for promyelocytic leukemia. Proc Natl Acad Sci USA 105: 4826-4831, 2008.

4. Kim JH, Park SH, Kim YW, Ha JM, Bae SS, Lee GS, Cho SI, Choi BT and Shin HK: The traditional herbal medicine, Dangkwisoo-San, prevents cerebral ischemic injury through nitric oxide-dependent mechanisms. Evid Based Complement Alternat Med 2011: 718302, 2011.

5. Li R, Guo M, Zhang G, Xu X and Li Q: Nicotiflorin reduces cerebral ischemic damage and upregulates endothelial nitric oxide synthase in primarily cultured rat cerebral blood vessel endothelial cells. J Ethnopharmacol 107: 143-150, 2006.

6. Wang N, Minatoguchi S, Arai M, Uno Y, Hashimoto K, Xue-Hai C, Fukuda K, Akao S, Takemura G and Fujiwara H: Lindera strychnifolia is protective against post-ischemic myocardial dysfunction through scavenging hydroxyl radicals and opening the mitochondrial KATP channels in isolated rat hearts. Am J Chin Med 32: 587-598, 2004.

7. Ward SM, Burns AJ, Torihashi S and Sanders KM: Mutation of the proto-oncogene c-kit blocks development of interstitial cells and electrical rhythmicity in murine intestine. J Physiol 480 : 91-97, 1994.

8. Huizinga JD, Thuneberg L, Klüppel M, Malysz J, Mikkelsen HB and Bernstein A: W/kit gene required for interstitial cells of Cajal and for intestinal pacemaker activity. Nature 373: 347-349, 1995

9. Sanders KM: A case for interstitial cells of Cajal as pacemakers and mediators of neurotransmission in the gastrointestinal tract. Gastroenterology 111: 492-515, 1996.

10. Kim BJ, Lim HH, Yang DK, Jun JY, Chang IY, Park CS, So I, Stanfield PR and Kim KW: Melastatin-type transient receptor potential channel 7 is required for intestinal pacemaking activity. Gastroenterology 129: 1504-1517, 2005.
11. Goto K, Matsuoka S and Noma A: Two types of spontaneous depolarizations in the interstitial cells freshly prepared from the murine small intestine. J Physiol 559: 411-422, 2004.

12. Huizinga JD, Chang G, Diamant NE and El-Sharkawy TY: Electrophysiological basis of excitation of canine colonic circular muscle by cholinergic agents and substance P. J Pharmacol Exp Ther 231: 692-699, 1984.

13. Inoue R and Chen S: Physiology of muscarinic receptor operated nonselective cation channels in guinea-pig ileal smooth muscle. Exs 66: 261-268, 1993.

14. Epperson A, Hatton WJ, Callaghan B, Doherty P, Walker RL, Sanders KM, Ward SM and Horowitz B: Molecular markers expressed in cultured and freshly isolated interstitial cells of Cajal. Am J Physiol Cell Physiol 279: C529-C539, 2000.

15. Komori S, Kawai M, Takewaki T and Ohashi H: GTP-binding protein involvement in membrane currents evoked by carbachol and histamine in guinea-pig ileal muscle. J Physiol 450: 105-126, 1992.

16. Ogata $\mathrm{R}$, Inoue $\mathrm{Y}$, Nakano $\mathrm{H}$, Ito $\mathrm{Y}$ and Kitamura $\mathrm{K}$ : Oestradiol-induced relaxation of rabbit basilar artery by inhibition of voltage-dependent Ca channels through GTP-binding protein. Br J Pharmacol 117: 351-359, 1996.

17. Aoyama M, Yamada A, Wang J, Ohya S, Furuzono S, Goto T, Hotta S, Ito Y, Matsubara T, Shimokata K, et al: Requirement of ryanodine receptors for pacemaker $\mathrm{Ca}^{2+}$ activity in ICC and HEK293 cells. J Cell Sci 117: 2813-2825, 2004.

18. Hirst GD, Dickens EJ and Edwards FR: Pacemaker shift in the gastric antrum of guinea-pigs produced by excitatory vagal stimulation involves intramuscular interstitial cells. J Physiol 541: 917-928, 2002.

19. Sanders KM: G protein-coupled receptors in gastrointestinal physiology. IV. Neural regulation of gastrointestinal smooth muscle. Am J Physiol 275: G1-G7, 1998. 